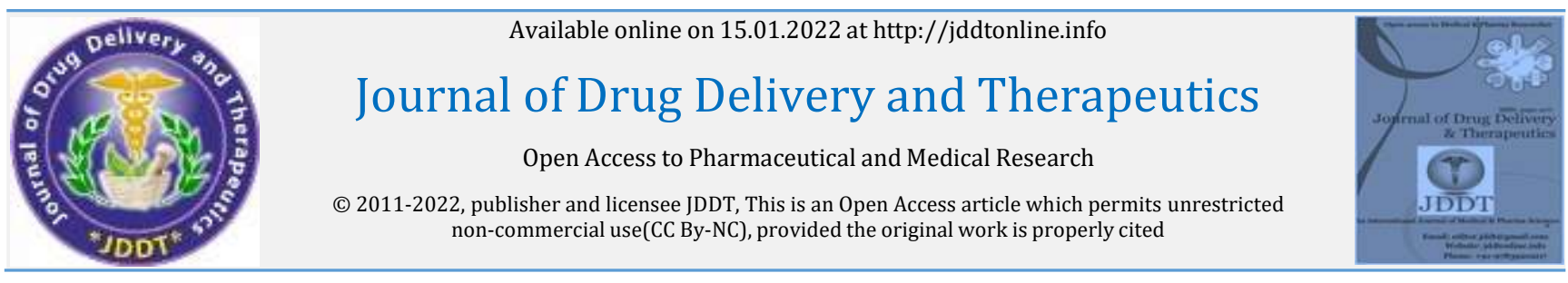

Open Access Full Text Article

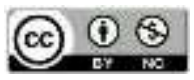

Research Paper

\title{
Pop-up book as a media for dental promotion to increase knowledge of dental health in elementary school students
}

\author{
Wiworo Haryani ${ }^{1}$, Irma HY Siregar ${ }^{2}$ \\ ${ }^{1}$ Department of Dental Health, Poltekkes Kemenkes Yogyakarta, Indonesia \\ ${ }^{2}$ Department of Dental Health, Poltekkes Kemenkes Semarang, Indonesia
}

\section{Article Info:}

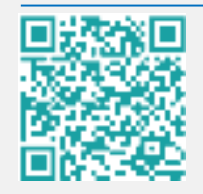

\section{Article History:}

Received 11 November 2021 Reviewed 27 December 2021 Accepted 04 January 2022 Published 15 January 2022

\section{Cite this article as:}

Haryani W, Siregar IHY, Pop-up book as a media for dental promotion to increase knowledge of dental health in elementary school students; Journal of Drug Delivery and Therapeutics. 2022; 12(1):42-44

DOI: http://dx.doi.org/10.22270/jddt.v12i1.5279

*Address for Correspondence:

Wiworo Haryani, Department of Dental Health

Poltekkes Kemenkes Yogyakarta, Indonesia

\begin{abstract}
Background: Elementary school children have a high risk of dental caries. The use of pop-up books as a medium so that elementary school students better understand the importance of dental health knowledge and how to brush their teeth properly and correctly. Purpose: This study was to analyze the effect of popup book media on increasing the dental health knowledge of elementary school students. Methods: The design of this study was a quasi-experimental with a pretest-posttest with one group design. The sampling technique was purposive sampling as many as 56 students. This research was conducted at SDN Nglengking, Minggir District, Sleman Regency, Yogyakarta Province from June to August 2019. The influence variable is the pop-up book media, and the affected variable is the level of dental health knowledge of elementary school students. Results: The results of the analysis of material experts and popup book media design experts showed a value of 35.5 , meaning that it was very valid and suitable to be used as a dental health education media. The significant value of the level of dental health knowledge before and after dental health education was carried out with pop-up book media $(p=0.000)$. Conclusion: pop-up book media about dental health is effective in increasing the dental health knowledge of elementary school students.
\end{abstract}

Keywords: Pop-up media, knowledge, dental health, elementary school students.

\section{INTRODUCTION}

The prevalence of people in Indonesia who have dental and oral problems is $25.9 \%$ in the population aged 10 years. The main factor that causes high dental and oral disease problems is the behavior of brushing teeth. The basic behavior for maintaining dental and oral health is brushing teeth properly and correctly. The definition of correct behavior in brushing teeth is the habit of brushing your teeth every day after breakfast and before going to bed at night. The data shows that the Indonesian population brushes their teeth in the morning and evening showers (76.6\%), brushing their teeth properly after breakfast and before going to bed at night, for Indonesia it is only $2.3 \% .^{1-3}$

Efforts to improve dental and oral health are dental and oral health counseling to individuals, families, groups, and communities, therefore the promotion of dental and oral health that can be easily absorbed by the community is important so that it can be applied in daily life in prevention efforts. the occurrence of dental and oral diseases to improve the degree of optimal dental and oral health. Efforts to prevent dental and oral diseases can be carried out by examining plaque, training in proper and proper toothbrushing techniques, cleaning tartar, preventing caries with fluoride and filling dental pits and fissures with fissure sealants.4-6

Dental health education is a planned and directed effort to achieve the goal of changing dental health behavior that is able to support better dental health. Health promotion is carried out with the aim of changing individual/community behavior in the health sector, making health something of value to society, helping individuals/communities to achieve a healthy life, and encouraging the development and proper use of health care facilities. 7,8

Health promotion is also carried out as an effort to increase children's knowledge. Lack of knowledge of children about dental and oral hygiene and its impact on health can affect children's attitudes and actions. ${ }^{9}$ Health promotion activities are influenced by factors such as methods, materials/messages, officers, and props/aids/media used. ${ }^{8}$ Elmunsyah et al. said that learning using media innovation is now important to improve the quality of learning. ${ }^{10}$

Elementary school students are strategic targets for the implementation of health programs, because apart from the large number, elementary school students are also an easy target to reach because they are well organized to provide education and skills. Children entering elementary school age, in general, children will have difficulty understanding abstract learning material. Learning media can go beyond the boundaries of promotional space. Health promotion media are all means or efforts to display information messages to be conveyed by communicators so that targets can increase their knowledge which is ultimately expected to change their behavior in a positive direction towards health. ${ }^{11,12}$

Efforts to increase knowledge through conventional counseling carried out with the oral lecture method for elementary school 
children showed that the increase in knowledge did not last long, this was supported by the opinion that approximately $75 \%$ of human knowledge is obtained through the eyes, while the other $25 \%$ is channeled, through other senses, so that it can be said that visual media makes it easier to convey and receive health information. ${ }^{13-15}$

A preliminary study conducted using the observation method on students at SDN Balangan in January 2019 on 20 students, showed that $68 \%$ of students had a low level of knowledge about dental health and $65 \%$ of children had their teeth brushing skills not done properly and correctly. Learning about dental health in children has received less attention, and one of the reasons is that the method used so far is still with lectures, children are less interested and feel bored, so that learning outcomes are not optimal.

Based on the preliminary study, the researcher will use a three-dimensional media, namely a pop-up book as an alternative to attract more students' attention in supporting students' understanding of dental health education. Pop-up book media is a book that can potentially move and interact through the use of paper mechanisms such as folds, slides, scrolls, and wheels. The advantages of pop up book media are three-dimensional (3D) media, each page contains interesting pictures so that children are more active and more enthusiastic about learning. Pop-up books are also easy to use and practical, more interesting for children as learning media, so that they are expected to increase children's motivation and learning outcomes. ${ }^{16,17}$

\section{MATERIALS AND METHODS}

The research design used a quasi-experimental design with a one-group pretest and posttest design. This research was conducted at SDN Nglengking, Minggir District, Sleman Regency, Yogyakarta Province from June to August 2019. The sampling technique used a purposive sampling technique as many as 56 students.

The independent variable in this study was dental health promotion with pop-up book media, while the dependent variable was dental health knowledge. The instrument for measuring the dental health knowledge variable was measured using a questionnaire. The questionnaire consists of 15 questions which include brushing teeth with toothpaste, maintaining dental health, consuming foods that are good for dental health and bad habits that affect dental health. Data analysis used paired sample test to analyze differences in knowledge before and after the intervention was given.

\section{RESULT}

Table 1. Pop-up book media validity results

\begin{tabular}{llll}
\hline Validator & $\begin{array}{l}\text { Acquisition } \\
\text { value }\end{array}$ & $\begin{array}{l}\text { Maximum } \\
\text { value }\end{array}$ & $\begin{array}{l}\text { Percentage } \\
(\%)\end{array}$ \\
\hline Material expert & 36 & 40 & 90 \\
Design expert & 35 & 40 & 87.5 \\
\hline
\end{tabular}

Table 1 shows that the results of the material expert's feasibility analysis show a total score of $36(90 \%)$ with very valid criteria and the design expert's feasibility results show a total score of $35(87.5 \%)$ with very valid criteria. The results of the analysis of material experts and design experts show that the dental health pop-up book media is very valid so it is suitable to be used as a dental health promotion media
Table 2. Frequency distribution of respondent characteristics

\begin{tabular}{clcc}
\hline No. & \multicolumn{1}{c}{ Variable } & N & Percentage (\%) \\
\hline 1 & Age & & \\
& 8-9 years & 28 & 50.0 \\
& 10-11 years & 28 & 50.0 \\
& total & 58 & 100 \\
2 & Gender & & \\
& Male & 22 & 39.3 \\
& Female & 34 & 60.7 \\
& total & 58 & 100 \\
\hline
\end{tabular}

Table 2 shows that the number of respondents aged 8-9 years is the same as those aged 10-11 years, namely 28 students $(50.0 \%)$ and shows that there are more female respondents than male, namely 34 students (60.7\%).

Table 3. Description of knowledge dental health

\begin{tabular}{lllll}
\hline \multirow{2}{*}{ Knowledge } & Pre-test & \multicolumn{3}{c}{ Post-test } \\
& $\mathrm{n}$ & $\%$ & $\mathrm{n}$ & $\%$ \\
\hline Good & 0 & 0 & 55 & 98.2 \\
Moderate & 34 & 60.7 & 0 & 0 \\
Enough & 22 & 39.3 & 1 & 1.8 \\
\hline Total & 56 & 100 & 56 & 100 \\
\hline
\end{tabular}

Table 3 shows that the level of knowledge before promotion of dental health with pop-up media with moderate criteria was $60.7 \%$ and increased after promotion to $98.2 \%$ good criteria

Table 4. The results of the effectiveness test of knowledge dental health before and after the intervention

\begin{tabular}{lccc}
\hline Knowledge & Mean \pm SD & $\Delta$ Mean & p-value \\
\hline Pre-test & $5.34 \pm 1.133$ & -7.838 & 0.000 \\
Post-test & $11.18 \pm 1.696$ & & \\
\hline
\end{tabular}

Table 4 shows that the results of the analysis of the difference test with the paired sample t-test there are differences in knowledge before and after intervention $p=0.000(p<0.05)$.

\section{DISCUSION}

The showed that there were more female respondents than male. In this study, the number of female respondents was more than male. Male and female students have the same strong potential to develop their talents, apply knowledge, and abilities. $^{18}$

The distribution of respondents based on age shows the age of the respondents as much as 28 students (50.0\%). Children at school age are very active in learning what is in their environment, so the urge to know and act on their environment is very large and the use of multimedia-based learning media can improve student learning outcomes because the learning process becomes effective, efficient and fun for children. ${ }^{19,20}$

The level of knowledge before promotion with moderate criteria was $60.7 \%$ and increased after promotion to $98.2 \%$. The benefits of dental health pop-up book media are to increase children's imagination, increase children's interest in reading and increase children's creativity. Pop-up books have advantages, including providing an interesting story starting with a dimensional display, namely in the image and when the book page is opened in certain sections. The use of pop-up book media helps students to be more active and have an interest in learning and can increase children's knowledge and learning motivation to start brushing their teeth, set the frequency of brushing teeth, which is twice per day, provide ways to maintain 
toothbrushes and tell children to brush their teeth correctly. ${ }^{21,22}$

Health promotion of brushing teeth using dental health popup book is done to increase a person's knowledge from not knowing to knowing and bad to good. This is reinforced by the opinion of Andriany et al. that elementary school age children always want to convey what they receive and know from others. ${ }^{19}$ Another opinion states that the pop-up book media is included in the very good and effective category as a learning media because it can increase student interest in learning, learning becomes interactive, pop-up books are easy to carry and easy to use. ${ }^{10}$ Pop-up media has a great influence on student learning outcomes. Pop-up books help students understand the material presented because pop-up books provide interesting stories, starting from a picture display that can move when the book page is opened.22

\section{CONCLUSION}

Based on the results of the study, it can be concluded that there is pop-up book media about dental health is effective in increasing the dental health knowledge of elementary school students.

\section{ACKNOWLEDGEMENTS}

The authors thank to Poltekkes Kemenkes Yogyakarta for funding this research, all participants and research assistants.

\section{CONFLICT OF INTEREST}

The authors declare that they have no conflict interests.

\section{ETHICAL CLEARANCE}

The study was conducted after obtaining approval from the Research Ethics Commission, Faculty of Dentistry, Gadjah Mada University No.00170/KKEP/FKG-UGM/EC/2019.

\section{REFERENCES}

1. Kemenkes RI. Riset kesehatan dasar tahun 2013. Badan Penelitian dan Pengembangan Kesehatan Kementrian Kesehatan RI. 2013;

2. Purnama T, Rasipin R, Santoso B. Pengaruh Pelatihan Tedi's Behavior Change Model pada Guru dan Orang Tua terhadap Keterampilan Menggosok Gigi Anak Prasekolah. Qual J Kesehatan. 2019; 13(2):75-81. https://doi.org/10.36082/qjk.v13i2.80

3. Sandstrom A, Cressey J, Stecksen-Blicks C. Tooth-brushing behaviour in 6-12 year olds. Int J Paediatr Dent. 2011; 21(1):439. https://doi.org/10.1111/j.1365-263X.2010.01080.x

4. Jurgensen N, Petersen PE. Promoting oral health of children through schools-Results from a WHO global survey 2012. Community Dent Heal. 2013; 30(4):204-18.

5. Sutarjo US. Profil Kesehatan Indonesia. Jakarta Kementrian Kesehatan RI. 2016;

6. Kemenkes RI. Pedoman Usaha Kesehatan Gigi Sekolah (UKGS). Jakarta Kementeri Kesehat RI. 2012;

7. Pudentiana Rr RE, Subandini SL, AMKG Sp. Bahan ajar pendidikan kesehatan gigi. 2019;
8. Notoatmodjo S. Promosi Kesehatan Teori dan Aplikasi, RinekaCipta. Jakarta; 2010.

9. Lossu FM, Pangemanan DHC, Wowor VNS. Hubungan pengetahuan kesehatan gigi dan mulut dengan indeks gingiva siswa SD Katolik 03 Frater Don Bosco Manado. e-GiGi. 2015; 3(2). https://doi.org/10.35790/eg.3.2.2015.10489

10. Elmunsyah H, Hidayat WN, Asfani K. Interactive learning media innovation: utilization of augmented reality and pop-up book to improve user's learning autonomy. In: Journal of Physics: Conference Series. IOP Publishing; 2019. p. 12031. https://doi.org/10.1088/1742-6596/1193/1/012031

11. Setiawati S, Siahaan N, Supartini Y, Sianturi Y. The Influence of Health Education How to Care for Teeth and Mouths on Knowledge, Attitude and Skills and the Status of Dental and Oral Health in Elementary School. Asian J Appl Sci. 2018; 6(6). https://doi.org/10.24203/ajas.v6i6.5553

12. Susilowati D. Promosi Kesehatan. Kementeri Kesehat RI. 2016;

13. Angelopoulou M V, Kavvadia K, Taoufik K, Oulis CJ. Comparative clinical study testing the effectiveness of school based oral health education using experiential learning or traditional lecturing in 10 year-old children. BMC Oral Health. 2015; 15(1):1-7. https://doi.org/10.1186/s12903-015-0036-4

14. Wahyuni R, Prameswari GN. Buku Gizi Braille sebagai Media Pendidikan untuk Meningkatkan Pengetahuan Anak Tunanetra. Unnes J Public Heal. 2016; 5(1):57-66. https://doi.org/10.15294/ujph.v5i1.9704

15. Yuniwati C, Yusnaini Y, Khatimah K. Pengaruh Media Audio Visual Dan Media Leaflet Terhadap Tingkat Pengetahuan Remaja Mas Darul Ihsan Aceh Besar Tentang Hiv/Aids. J Ilm PANNMED (Pharmacist, Anal Nurse, Nutr Midwivery, Environ Dent. 2018; 13(2):116-20. https://doi.org/10.36911/pannmed.v13i2.398

16. Anggraini W, Nurwahidah S, Asyhari A, Reftyawati D, Haka NB. Development of Pop-Up Book Integrated with Quranic Verses Learning Media on Temperature and Changes in Matter. In: Journal of Physics: Conference Series. IOP Publishing; 2019. p. 12084. https://doi.org/10.1088/1742-6596/1155/1/012084

17. Sari NE, Suryana D. Thematic Pop-Up Book as a Learning Media for Early Childhood Language Development. J Pendidik Usia Dini. 2019 13(1):43-57. https://doi.org/10.21009/10.21009/JPUD.131.04

18. Nina J. Perempuan Nuaulu: tradisionalisme dan kultur patriarki. Yayasan Pustaka Obor Indonesia; 2012.

19. Andriany P, Novita CF, Aqmaliya S. Perbandingan efektifitas media penyuluhan poster dan kartun animasi terhadap pengetahuankesehatan gigi dan mulut (Studi pada Siswa/i Kelas V SDN 24 Kota Banda Aceh). J Syiah Kuala Dent Soc. 2016; 1(1):65-72.

20. Arsyad MN. Penerapan Media Pembelajaran Berbasis Multimedia Interaktif Terhadap Mahasiswa IKIP Budi Utomo Malang. Agastya J Sej Dan Pembelajarannya. 2018; 8(2):188-98. https://doi.org/10.25273/ajsp.v8i2.2702

21. Syukur H, Mulyawan S. Penggunaan Media Pop Up Book dan Pengaruhnya Terhadap Peningkatan Pemahaman Siswa dalam Memahami Teks-Teks Bahasa Arab. EL-IBTIKAR J Pendidik Bhs Arab. 2019; 8(1):53-77. https://doi.org/10.24235/ibtikar.v8i1.4655

22. Rizkika N, Christiono S. Efektivitas buku pop-up terhadap pemahaman kesehatan gigi anak berkebutuhan khusus. Indones J Paediatr Dent. 2018; 1(1):22-5. 